JRNAL ПMПAH

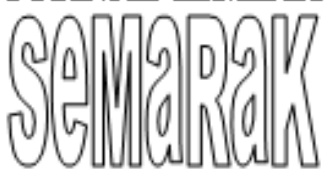

Jurnal Semarak,Vol.4,No.2,Juni 2021, Hal (67-80)

@Prodi Manajemen Fakultas Ekonomi Universitas Pamulang

\title{
PENGARUH CAPITAL ADEQUACY RATIO, UKURAN BANK DAN RISIKO PEMBIAYAAN TERHADAP RETURN ON ASSET PADA BANK UMUM SYARIAH DI INDONESIA PERIODE 2015 - 2019
}

\author{
Sutiman \\ Staf Pengajar Fakultas Ekonomi Universitas Pamulang \\ email: Dosen01673@unpam.ac.id
}

\begin{abstract}
ABSTRAK
Penelitian ini bertujuan untuk mengetahui pengaruh variabel capital adequacy ratio terhadap return on asset, mengetahui pengaruh variabeel ukuran bank terhadap return on asset, mengetahui pengaruh variabeel resiko pembiayaan terhadap return on asset, mengetahui pengaruh variabel capital adequacy ratio, ukuran bank dan resiko pembiayaan terhadap return on asset. Metode analisis yang digunakan adalah regresi berganda dengan menggunakan program SPSS 20.0, objek penelitian ini adalah bank umum syariah yang terdaftar di Indonesia periode 2015 - 2019. Hasil penelitian menunjukkan bahwa secara simultan rasio kecukupan modal, ukuran bank dan risiko pembiayaan berpengaruh terhadap return on asset dilihat dari nilai $F_{\text {hitung }}(9139)>F_{\text {tabel }}(3,27)$. Secara parsial resiko pembiayaan berpengaruh terhadap retun on asset, dilihat dari nilai $t_{\text {hitung }}(-3,371)<\mathrm{t}_{\text {tabel }}(-2,01)$. Rasio kecukupan modal tidak berpengaruh terhadap return on asset, dilihat dari nilai $t_{\text {hitung }}(1,674)<\mathrm{t}_{\text {tabel }}(2,01)$ dan ukuran bank tidak berpengaruh terhadap return on asset, dilihat dari nilai $t_{\text {hitung }}(1,126)<t_{\text {tabel }}(2,01)$. Berdasarkan hasil koefisien determinasi adalah 0,293. Hal ini berarti 29,3\% variasi dari return on asset bisa dijelaskan oleh variasi variabel independen (capital adequacy ratio, ukuran bank dan resiko pembiayaan). Sedangkan sisanya $(100 \%-29,3 \%=70,7 \%)$ dijelaskan oleh variabel lain yang tidak ada dalam penelitian ini, seperti financing deposit ratio, beban operasional dan pendapatan operasional, nett profit margin.
\end{abstract}

Kata kunci:capital adequacy ratio, ukuran bank, resiko pembiayaan, return on asset

\begin{abstract}
This study aims to determine the influence of variable capital adequacy ratio on return on asset, know the influence of variabeel bank size on return on asset, know the influence of variabeel financing risk on return on asset, know the influence of variable capital adequacy ratio, bank size and financing risk to return on asset. The analysis method used is multiple regression using SPSS 20.0 program, the object of this research is sharia commercial banks registered in Indonesia for the period 2015 - 2019. The results showed that simultaneously the ratio of capital adequacy, bank size and financing risk had an effect on return on assets as seen from the value of Fhitung (9139) > Ftabel (3.27). Partial financing risk affects the retun on assets, judging by the value of thitung $(-3,371)<$ ttabel $(-2.01)$. The capital adequacy ratio has no effect on return on assets, judging by the value of thitung $(1,674)<$ ttabel $(2.01)$ and the size of the bank has no effect on return on assets, judging by the value of thitung $(1,126)<$ ttabel (2.01). Based on the result of the coefficient of determination is 0.293 . This means that $29.3 \%$ variation of return on assets can be explained by independent variable variations (capital adequacy ratio, bank size and financing risk). While the rest $(100 \%-29.3 \%=70.7 \%)$ explained by other variables not present in this study, such as financing deposit ratio, operating expenses and operating income, nett profit margin.
\end{abstract}


JURAL ПMПAH

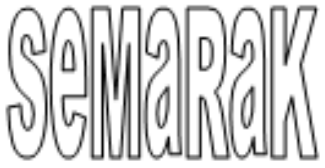

P-ISSN 2615-6849, E-ISSN 2622-3686

Jurnal Semarak,Vol.4,No.2,Juni 2021, Hal (67-80)

@Prodi Manajemen Fakultas Ekonomi Universitas Pamulang

\section{Keywords: capital adequacy ratio, bank size, financing risk, return on assets}

\section{PENDAhULUAN}

\section{A. Latar Belakang}

Sepuluh tahun setelah krisis keuangan tahun 1998, Indonesia kembali mengalami krisis yang menyebabkan perlambatan pertumbuhan ekonomi, yang pada tahun 2007 tingkat pertumbuhan ekonomi negara mencapai $6,7 \%$ dan pada tahun 2008 hanya $6,1 \%$.

Dampak lainnya mengalami penurunan neraca pembayaran, tekanan nilai tukar dan dorongan tingkat inflasi. Kasus Bank Century adalah salah satu kasus yang terjadi di Indonesia. Bank ini perlu diselamatkan karena berdampak negatif pada perbankan nasional dan likuiditas nasional. Kasus bank Century adalah contoh bank yang mengalami masalah kesehatan (Rotinsulu, 2015)

Setelah masa krisis, perbankan di Indonesia mulai berbenah. Terlihat dari profitabilitas yang mempunyai trend meningkat dari tahun 2001 hingga 2006. Hal ini dikarenakan krisis 1998 telah mempengaruhi perubahan dalam beberapa aspek, yaitu transparansi dan efektifitas, profesionalisme dan kompetensi, pemenuhan ketentuan perbankan yang bersifat prinsip kehati-hatian (Sudarsono, 2009).
Kinerja perbankan syariah diyakini lebih baik dibanding bank konvensional. Hal ini dibuktikan dengan bertahannya bank-bank syariah saat terjadi krisis ekonomi tahun 1998. Namun 5 tahun belakang ini kinerja keuangan bank syariah yang dilihat dari rasio keuangan ROA mengalami stagnansi. Berdasarkan statistik perbankan syariah yang diperoleh dari Otoritas Jasa Keuangan (OJK). Diketahui performa keuangan yang diukur dengan ROA mengalami stagnansi ditahun 2017.

Keadaan bank syariah yang semakin berkembang sejak adanya UU No. 28 Tahun 2008 tentang perbankan syariah yang memberikan landasan yang lebih jelas bagi bank syariah. Perkembangan perbankan syariah di Indonesia terlihat dari jumlah bank umum syariah (BUS) yang sekarang mencapai 14 bank, unit usaha syariah (UUS) sebanyak 20 bank, dan bank pembiayaan rakyat syariah (BPRS) sebanyak 165 bank (SPS BI, Juli 2019).

Hal tersebut dapat disimpulkan bahwa perkembangan bank syariah semakin banyak hadir di tengah-tengah perbankan konvensional yang menunjukkan pula semakin banyak 
JRNAL ПMПAH

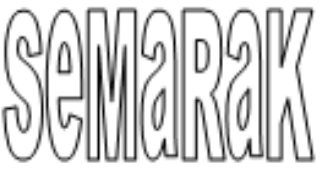

P-ISSN 2615-6849, E-ISSN 2622-3686

Jurnal Semarak,Vol.4,No.2,Juni 2021, Hal (67-80)

@Prodi Manajemen Fakultas Ekonomi Universitas Pamulang masyarakat yang ingin memperoleh layanan jasa perbankan dengan menggunakan prinsip syariah (Nunung indrawati, 2018)

Bank memberikan kontribusi besar terhadap perekonomian suatu negara. Sebagai lembaga intermediasi bank mempunyai peranan sebagai jalur pembiayaan, penyimpanan dan peminjaman sehingga pada akhirnya mensejahterakan kehidupan masyarakat. Fungsi perbankan yang sangat penting maka bank dipaksa untuk menjadi lebih kompetitif dan menerapkan sistem penilaian tingkat kesehatan bank.

Salah satu indikator yang paling tepat untuk mengukur kinerja keuangan suatu perusahaan adalah dari rasio profitabilitas. Perbankan syariah yang beroperasi di Indonesia berlomba-lomba untuk mencapai tingkat keuntungan yang maksimal karena semakin tinggi profitabilitas perusahaan,

Berdasarkan penjelasan yang telah diuraikan di atas, penulis berminat menjalankan kajian dengan tajuk "Pengaruh Capital Adequacy Ratio, Ukuran Bank Dan Risiko Pembiayaan Terhadap Return On Asset Pada Bank Umum Syariah Di Indonesia Periode 2015 - 2019".

\section{B. Perumusan Masalah}

Berdasarkan latar belakang permasalahan di atas, maka masalahmasalah penelitian dapat dirumuskan sebagai berikut:

1. Bagaimana pengaruh secara parsial antara capital adequacy ratio terhadap return on asset?

2. Bagaimana pengaruh secara parsial antara ukuran bank terhadap return on asset?

3. Bagaimana pengaruh secara parsial antara risiko pembiayaan terhadap return on asset?

4. Bagaimana pengaruh secara simultan antara capital asdequacy ratio, ukuran bank dan resiko pembiayaan terhadap return on asset?

\section{Tujuan Penelitian}

Berdasarkan latar belakang masalah dan perumusan masalah, maka tujuan dalam penelitian ini adalah sebagai berikut:

1. Untuk menganalisis pengaruh secara parsial antara capital asdequacy ratio terhadap return on asset.

2. Untuk menganalisis pengaruh secara parsial antara ukuran bank terhadap return on asset.

3. Untuk menganalisis pengaruh secara parsial antara risiko pembiayaan terhadap return on asset.

4. Untuk menganalisis pengaruh secara simultan antara capital asdequacy ratio, 
JRNAL ПMПAH

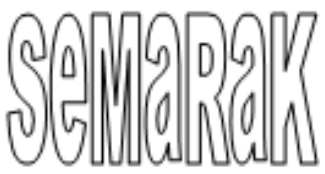

P-ISSN 2615-6849, E-ISSN 2622-3686

Jurnal Semarak,Vol.4,No.2,Juni 2021, Hal (67-80)

@Prodi Manajemen Fakultas Ekonomi Universitas Pamulang ukuran bank dan resiko pembiayaan terhadap return on asset.

\section{TINJAUAN PUSTAKA}

\section{A. Kinerja Keuangan Bank}

Kinerja bank merupakan gambaran prestasi yang dicapai bank dalam operasionalnya, baik menyangkut aspek dari keuangan, pemasaran, penghimpunan, dan penyaluran dana, teknologi maupun sumber daya manusia. Kinerja keuangan bank merupakan gambaran kondisi keuangan bank pada suatu periode tertentu baik menyangkut aspek penghimpunan dana maupun penyaluran dana yang biasannya diukur dengan indikator kecukupan modal, likuiditas, profitabilitas bank (Jumingan, 2006).

Menurut (Rodoni, 2014), alat analisis yang dipergunakan untuk menganalisa kinerja keuangan, diantaranya adalah analisis rasio, proporsional, $D u$ Pont System of Analysis, dan EVA (Economic Value Added). Rasio keuangan dihitung berdasarkan financial statement yang telah tersedia, yang terdiri dari balance sheet atau neraca dan income statement atau laporan laba rugi. Rasio-rasio keuangan umumnya berupa liquidity ratio, activity ratio, debt ratio, profitability ratio.

\section{B. Return on Asset (Y)}

Return on Asset (ROA) digunakan untuk mengukur kemampuan manajemen bank dalam memperoleh keuntungan secara keseluruhan, semakin besar ROA suatu bank, semakin besar pula tingkat keuntungan yang dicapai bank tersebut dari segi penggunaan asset. Selain itu, Return On Asset digunakan untuk mengukur profitabilitas bank karena bank Indonesia sebagai pembina dan peng awas perbankan lebih mengutamakan nilai profitabilitas suatu bank, diukur dengan asset yang dananya sebagian besar dari dana simpanan masyarakat (Dendawijaya, 2009).

Return On Asset (ROA) adalah rasio yang mampu mengukur kemampuan perusahaan menghasilkan laba pada masa lalu (Hanafi,2012:157). Jika ROA suatu bank semakin besar, maka semakin besar pula tingkat keuntungan yang dicapai bank tersebut dan semakin baik posisi bank tersebut dari pengamanan asset. Menurut Oktaviani (2012), laba yang tinggi membuat bank mendapat kepercayaan dari masyarakat yang memungkinkan bank untuk menghimpun modal yang lebih banyak sehingga bank memperoleh kesempatan menyalurkan dana dengan lebih luas.

Nilai ROA yang semakin mendekati 1, hal itu berarti semakin baik keuntungan (profitabilitas) perusahaan karena setiap yang ada dapat menghasilkan laba. Dengan demikian, dapat disimpulkan apabila semakin tinggi Return On Asset hal itu mengindikasikan bahwa kinerja 
JRNAL ПММАH

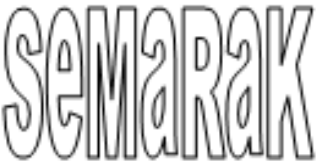

P-ISSN 2615-6849, E-ISSN 2622-3686

Jurnal Semarak,Vol.4,No.2,Juni 2021, Hal (67-80)

@Prodi Manajemen Fakultas Ekonomi Universitas Pamulang perusahaan semakin efektif, sehingga

struktur modal perusahaan dapat mencerminkan aktivitas pembiayaan dengan tingkat pengembalian atau laba yang didapat (Kasmir, 2012:197).

Bank Indonesia menetapkan besarnya ROA yaitu 1,5 persen. Menurut SE BI Nomor 13/24/DPNP tanggal 25 Oktober 2011, rumus dari ROA adalah:

$$
\text { ROA }=\frac{\text { Laba Sebelum Pajak }}{\text { Total Aktiva }} x 100 \%
$$

\section{Capital Adequacy Ratio $\left(\mathbf{X}_{1}\right)$}

Capital Adequacy Ratio (CAR) merupakan indikator yang sering digunakan untuk mengukur tingkat kecukupan modal bank. CAR dapat diperoleh melalui perhitungan rasio atau perbandingan antara modal sendiri dengan ATMR

\section{Capital Adequacy Ratio (CAR)} merupakan proksi utama permodalan bank. Menurut Dietrich, bank dengan modal yang tinggi dianggap relatif lebih aman dibandingkan dengan bank modal yang rendah, hal ini disebabkan bank dengan modal yang tinggi biasanya memiliki kebutuhan yang lebih rendah dari pada pendanaan eksternal. Bank Indonesia menetapkan besarnya rasio CAR yaitu minimum 8 persen. Menurut SE BI Nomor 13/24/DPNP tanggal 25 Oktober 2011, rumus dari rasio CAR adalah:

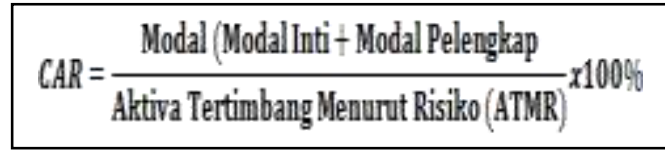

\section{Ukuran Bank}

Ukuran Bank didefinisikan sebagai ukuran besar kecilnya suatu bank tersebut. Ukuran bank dapat dinyatakan dalam total asset (aktiva), penjualan, dan kapitalisasi. Semakin besar penjualan aktiva, dan kapitalisasi pasar maka semakin besar pula ukuran perusahaan itu.

Menurut Ardi dan Lana (2006) besar kecilnya perusahaan dapat dilihat dari total asset yang dimiliki perusahaan tersebut. Dalam perusahaan perbankian untuk mengetahui besarnya ukuran perusahaan dapat dilihat dari jumlah total asset yang dimiliki. Asset yang dimiliki bank terdiri atas kas, penempatan pada bank lain, surat-surat berharga, pembiayaan yang disalurkan, penyertaan, biaya dibayar dimuka, aktiva tetap, aktiva sewa guna usaha,aktiva lain-lain.

Rasio ukuran bank diperoleh dari logaritma natural dari total assets yang dimiliki bank yang bersangkutan pada periode tertentu. Menurut Kosmidou et al. (2008), bank yang lebih besar ukuran asetnya lebih menguntungkan dari pada bank yang ukuran asetnya kecil, karena ukuran bank yang lebih besar mempunyai tingkat efisiensi yang lebih 
JRNAL ПMПAH

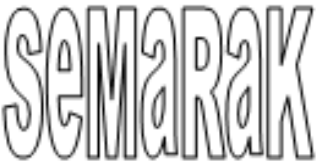

P-ISSN 2615-6849, E-ISSN 2622-3686

Jurnal Semarak,Vol.4,No.2,Juni 2021, Hal (67-80)

@Prodi Manajemen Fakultas Ekonomi Universitas Pamulang tinggi. Rumus variabel ukuran perusahaan adalah:

\section{Size $=$ Ln Total (Aktiva)}

\section{E. Resiko Pembiayaan}

NPF atau dikenal dengan risiko pembiayaan adalah risiko akibat ketidak mampuan nasabah dalam mengembalikan pinjaman yang telah diberikan oleh bank beserta imbalannya dalam jangka waktu tertentu. Non Performing Financing adalah suatu rasio yang membandingkan tingkat pembiayaan bermasalah terhadap total pembiayaan yang diberikan.

Rasio ini menunjukkan pembiayaan bermasalah yang tergolong dari

pembiayaan kurang lancar, diragukan dan macet (Pramuka, 2010). Rasio ini membandingkan antara jumlah pembiayaan bermasalah dengan seluruh pembiayaan yang ada.

Besaran rasio Non Performing

Financing / Non Performing Loan yang ditetapkan oleh Bank Indonesia berdasarkan Peraturan BI Nomor 15/2/PBI/2013 adalah maksimal 5\%. Jika melebihi 5\% maka akan mempengaruhi tingkat kesehatan bank yang bersangkutan. Menurut Zulifiah dan Susilowibowo (2014) nilai NPF dapat dirumuskan sebagai berikut:

$$
\text { NPF }=\frac{\text { Junlah Pembiayaan Bermasalah }}{\text { Total Pembiayaan }} \times 100 \%
$$

\section{F. Hipotesis Penelitian}

Hipotesis yang diuji dalam penelitian ini berkaitan dengan ada atau tidaknya pengaruh yang signifikan dari seperangkat variabel bebas (independent variable) terhadap variabel terikat (dependent variable). Adapan hipotesis yang diuji yakni sebagai berikut:

1. $\mathrm{H}_{\mathrm{o} 1}$ : Diduga variabel capital adequacy ratio tidak berpengaruh secara parsial terhadap return on asset

$\mathrm{H}_{\mathrm{a} 1} \quad$ : Diduga variabel capital adequacy ratio berpengaruh secara parsial terhadap return on asset.

2. $\mathrm{H}_{\mathrm{o} 2}$ : Diduga variabel ukuran bank tidak berpengaruh secara parsial terhadap return on asset.

$\mathrm{H}_{\mathrm{a} 2} \quad$ : Diduga variabel ukuran bank berpengaruh secara parsial terhadap return on asset.

3. $\mathrm{H}_{03}$ : Diduga resiko pembiayaan tidak berpengaruh secara parsial terhadap return on asset. 
JRNAL ПMПAH

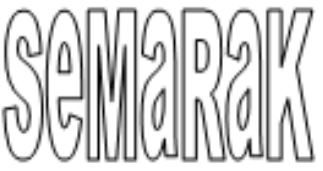

P-ISSN 2615-6849, E-ISSN 2622-3686

Jurnal Semarak,Vol.4,No.2,Juni 2021, Hal (67-80)

@Prodi Manajemen Fakultas Ekonomi Universitas Pamulang
$\mathrm{H}_{\mathrm{a} 3}$ : Diduga resiko pembiayaan berpengaruh secara parsial terhadap return on asset.

4. $\mathrm{H}_{04}$ : Diduga variabel capital adequacy ratio, ukuran bank dan resiko pembiayaan tidak berpengaruh secara simultan terhadap return on asset.

$\mathrm{H}_{\mathrm{a} 4} \quad$ : Diduga variabel capital adequacy ratio, ukuran bank dan resiko pembiayaan berpengaruh secara simultan terhadap return on asset.

\section{METODE PENELITIAN}

Objek dalam penelitian ini adalah bank umum syariah yang terdaftar di Indonesia periode 2015 - 2019. Metode yang digunakan dalam penelitian ini adalah metode studi kasus yang merupakan salah satu penelitian deskriptif, dengan studi ini diharapkan dapat diungkap secara mendalam variabel-variabel yang akan dapat menggambarkan tentang Pengaruh capital adequacy ratio, ukuran bank dan resiko kredit terhadap return on asset Pada bank umum syariah di Indonesia periode 2015 - 2019.

Data-data yang digunakan dalam penelitian ini, baik yang bertujuan untuk mendeskripsikan maupun untuk menganalisis, diperoleh dari data sekunder yang bersifat kuantitatif. Data sekunder adalah data yang informasinya diperoleh secara tidak langsung dari perusahaan. Data sekunder adalah sumber data penelitian yang diperoleh peneliti secara tidak langsung melalui perantara (diperoleh dan dicatat oleh pihak lain). Data-data sekunder tersebut berupa rasio-rasio laporan keuangan dari laporan keuangan perusahaan perbankan syariah yang ada di Indonesia.

Sampel yang digunakan dengan metode purposive sampling. Metode purposive sampling yaitu sampel yang diambil berdasarkan kriteria-kriteria tertentu untuk mendapatkan sampel yang sesuai dengan tujuan penelitian.

Teknik pengumpulan data dengan menggunakan analisis laporan keuangan. Sampel yang dijadikan objek penelitian sebanyak 12 bank umum syariah periode 2015 sampai 2019.

\section{HASIL DAN PEMBAHASAN}

\section{A. Gambaran Objek Penelitian}

Deregulasi perbankan dimulai sejak tahun 1983. Pada tahun tersebut, BI memberikan keleluasaan kepada bankbank untuk menetapkan suku bunga. Pemerintah berharap dengan kebijakan deregulasi perbankan maka akan tercipta 
JRNAL ПММАH

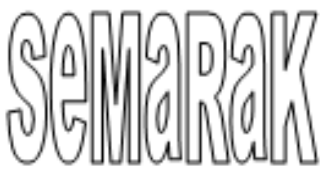

P-ISSN 2615-6849, E-ISSN 2622-3686

Jurnal Semarak,Vol.4,No.2,Juni 2021, Hal (67-80)

@Prodi Manajemen Fakultas Ekonomi Universitas Pamulang kondisi dunia perbankan yang lebih efisien dan kuat dalam menopang perekonomian. Pada tahun 1983 tersebut pemerintah Indonesia pernah berencana menerapkan "sistem bagi hasil" dalam perkreditan yang merupakan konsep dari perbankan syariah.

Pada tahun 1988, Pemerintah mengeluarkan Paket Kebijakan Deregulasi Perbankan 1988 (Pakto 88) yang membuka kesempatan seluas-luasnya kepada bisnis perbankan harus dibuka seluas-luasnya untuk menunjang pembangunan (liberalisasi sistem perbankan). Meskipun lebih banyak bank konvensional yang berdiri, beberapa usaha-usah perbankan yang bersifat daerah yang berasaskan syariah juga mulai bermunculan.

Inisiatif pendirian bank Islam Indoensia dimulai pada tahun 1980 melalui diskusi-diskusi bertemakan bank Islam sebagai pilar ekonomi Islam. Sebagai uji coba, gagasan perbankan Islam dipraktekkan dalam skala yang relatif terbatas di antaranya di Bandung (Bait At-Tamwil Salman ITB) dan di Jakarta (Koperasi Ridho Gusti).

Berikut ini nama bank yang menjadi objek dalam penelitian ini:

Tabel 1

Daftar Nama bank Umum Syariah

\begin{tabular}{|c|l|}
\hline No & \multicolumn{1}{|c|}{ Nama Perusahaan } \\
\hline 1. & Bank Muarualat Indouesja \\
\hline 2. & Bank Syariah Mandiri \\
\hline 3. & Bank Victoria Syariah \\
\hline 4. & BRI Syariah \\
\hline 5. & BNI Syariah \\
\hline 6. & Bank Syariah Mega Indonesia \\
\hline 7. & Bark Panin Dubai Svariah \\
\hline 8. & Bank Syariah Bukopin \\
\hline 9. & BCA Syariah \\
\hline 10. & Maybank Syariah \\
\hline 11. & BTPN Syariah \\
\hline 12. & B.PD Jawa Barat Banten Syariah \\
\hline
\end{tabular}

\section{B. Hasil Analisis dan Pembahasan}

\section{Hasil Uji Asumsi Klasik}

a. Hasil Uji Normalitas Data

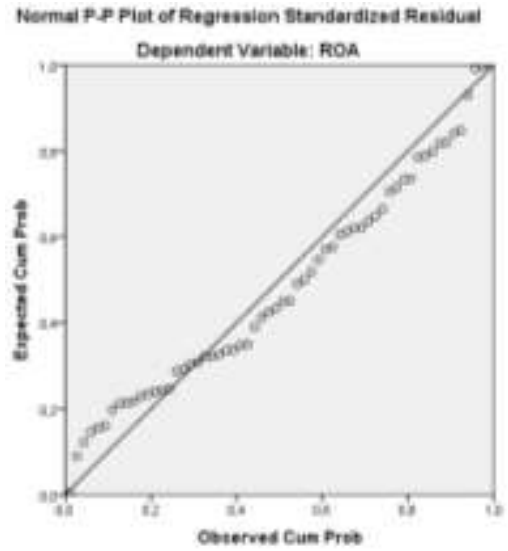

Gambar 1

\section{Hasil Uji Normalitas Data}

Dari grafik di atas dapat dilihat bahwa data penelitian memiliki penyebaran dan distribusi yang normal karena data memusat pada nilai rata-rata dan median atau nilai plot PP terletak digaris diagonal, maka dapat dikatakan bahwa data tersebut berdistribusi normal.

\section{b. Hasil Uji Multikolinearitas}


JRNAL ПMПAH

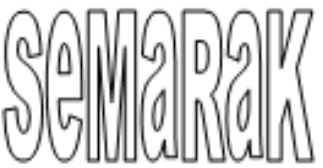

P-ISSN 2615-6849, E-ISSN 2622-3686

Jurnal Semarak,Vol.4,No.2,Juni 2021, Hal (67-80)

@Prodi Manajemen Fakultas Ekonomi Universitas Pamulang
Tabel 1

\section{Hasil Uji Multikolinearitas}

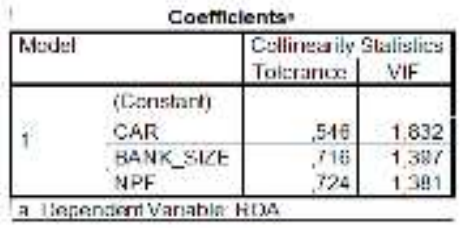

Nilai VIF yang diperbolehkan hanya mencapai 10 dan memiliki nilai tolerance lebih dari 0,10 . Maka data di atas dapat dipastikan tidak terjadi gejala multikolinearitas. Karena data di atas menunjukan bahwa nilai VIF lebih kecil dari 10.

\section{c. Hasil Uji Autokorelasi}

Tabel 2

\section{Hasil Uji Autokorelasi}

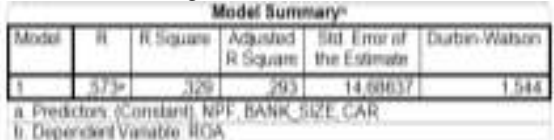

Pada tabel di atas diketahui nilai Durbin Watson (d) sebesar 1,544, berdasarkan nilai durbin watson sebesar 1,544 maka hasil membuktikan tidak terjadi autokolerasi, karena nilai DW berada pada angka -2 sampai dengan +2 , maka dapat disimpulkan tidak ada autokorelasi baik positif maupun negatif.

\section{d. Hasil Uji Heteroskedastisitas}

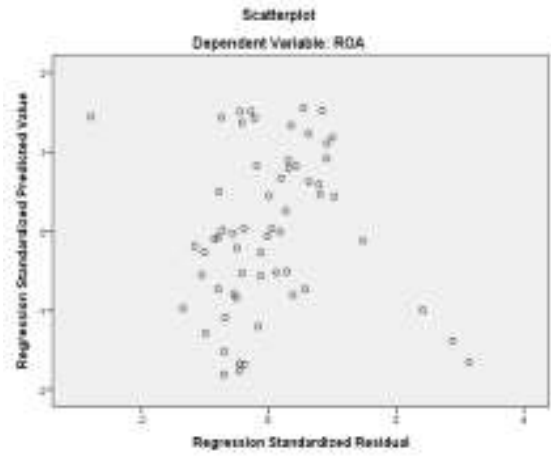

Gambar 2

Hasil Uji Heteroskedastisitas

Pada gambar di atas terlihat bahwa titik-titik menyebar di atas dan di bawah angka nol pada sumbu Y dan tidak terlihat pola tertentu. Dengan demikian pada persamaan regresi linier berganda dalam model ini tidak ada gejala atau tidak ada heteroskedastisitas.

\section{Hasil Analisis Koefisien Regresi Linier Berganda}

a. Hasil Koefisien Determinasi

\section{Tabel 3}

Hasil Koefisien

Determinasi (Adjusted $\mathbf{R}^{2}$ )

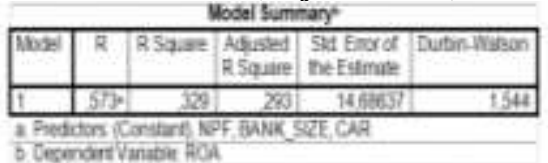

Hasil pengujian menunjukkan besarnya koefisien korelasi berganda (R), koefisien determinasi (Adj $R$ Square) dan koefisien determinasi yang disesuaikan (Adjusted $R$ Square). Berdasarkan tabel model summary $^{b}$ di atas diperoleh bahwa 
JRNAL ПMாAH

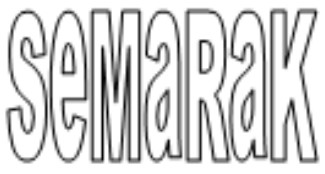

P-ISSN 2615-6849, E-ISSN 2622-3686

Jurnal Semarak,Vol.4,No.2,Juni 2021, Hal (67-80)

@Prodi Manajemen Fakultas Ekonomi Universitas Pamulang nilai koefisien korelasi berganda $(\mathrm{R})$ sebesar 0,579. Ini menunjukkan bahwa variabel capital adequacy ratio, ukuran bank dan resiko pembiayaan terhadap return on asset mempunyai hubungan yang sedang. Hasil pada tabel di atas juga menunjukkan bahwa nilai koefisien determinasi $(R \quad$ Square $)$ sebesar 0,329 dan nilai koefisien determinasi yang sudah disesuaikan (Adjusted $R$ Square) adalah 0,293. Hal ini berarti $29,3 \%$ variasi dari return on asset bisa dijelaskan oleh variasi variabel independen (capital adequacy ratio, ukuran bank dan resiko pembiayaan). Sedangkan sisanya $(100 \%-29,3 \%=70,7 \%)$ dijelaskan oleh variabel lain yang tidak ada dalam penelitian ini, seperti financing deposit ratio, beban operasional dan pendapatan operasional, nett profit margin.

\section{b. Hasil Koefisien Persamaan}

\section{Regresi Linier Berganda}

Analisis regresi linier berganda adalah suatu uji yang digunakan untuk mengetahui seberapa besar tingkat pengaruh antar variabel independen (capital adequacy ratio, ukuran bank dan resiko pembiayaan) terhadap variabel dependen (return on asset). Adapun hasil regresi linier berganda pengaruh capital adequacy ratio, ukuran bank dan resiko pembiayaan terhadap return on asset adalah sebagai berikut:

Tabel 4

Hasil Koefisien Persamaan

Regresi Linier Berganda

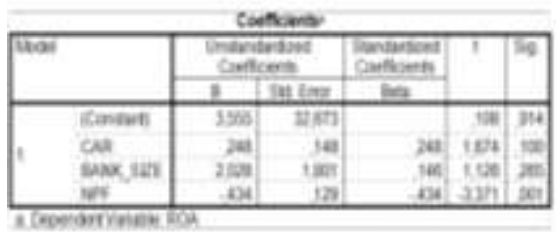

Tabel di atas dapat dirumuskan suatu persamaan regresi untuk mengetahui pengaruh capital adequacy ratio, ukuran bank dan resiko pembiayaan terhadap return on asset sebagai berikut: $\mathrm{Y}=\mathrm{a}+\mathrm{bx}_{1}+\mathrm{bx}_{2}+\mathrm{bx}_{3}$ $\begin{aligned} Y= & 3,555+0,248 X_{1}+2,028 X_{2}- \\ & 0,434 X_{3}\end{aligned}$

Pada persamaan regresi di atas menunjukkan nilai konstanta sebesar 3,555. Hal ini menyatakan bahwa jika variabel capital adequacy ratio, ukuran bank dan resiko pembiayaan dianggap konstan atau bernilai 0 (nol), maka return on asset akan meningkat sebesar 3,555 satuan.

Koefisien regresi pada variabel capital adequacy ratio sebesar 0,248 , hal ini berarti jika variabel capital adequacy ratio bertambah 
JRNAL ПMாAH

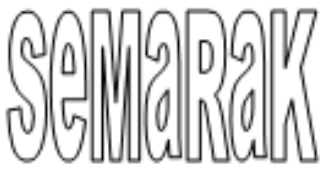

P-ISSN 2615-6849, E-ISSN 2622-3686

Jurnal Semarak,Vol.4,No.2,Juni 2021, Hal (67-80)

@Prodi Manajemen Fakultas Ekonomi Universitas Pamulang satu satuan maka variabel return on asset akan meningkat sebesar 0,248 satuan, dengan catatan variabel lain dianggap konstan.

Koefisien regresi pada variabel ukuran bank sebesar 2,028, hal ini berarti jika variabel ukuran bank bertambah satu satuan maka variabel ukuran bank akan meningkat sebesar 2,028 satuan, dengan catatan variabel lain dianggap konstan.

Koefisien regresi pada variabel resiko pembiayaan sebesar $-0,434$, hal ini berarti jika variabel resiko pembiayaan bertambah satu satuan maka variabel return on asset akan menurun sebesar 0,434 satuan, dengan catatan variabel lain dianggap konstan.

\section{Hasil Uji Hipotesis}

\section{a. Hasil Uji Statistik F (Simultan)}

Uji F dilakukan untuk melihat pengaruh variabel capital adequacy ratio, ukuran bank dan resiko pembiayaan secara keseluruhan terhadap variabel return on asset. Berikut ini adalah hasil uji secara simultan, diperoleh hasil uji Anova sebagai berikut:

Tabel 5

Hasil Uji Statistik F (Simultan)

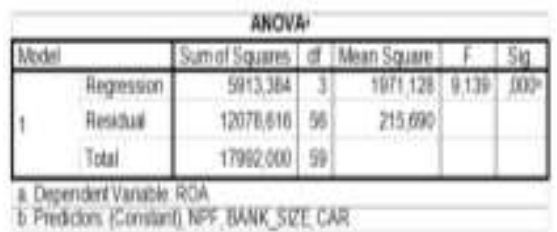

Hasil uji $\mathrm{F}$ dapat dilihat pada tabel di atas nilai $F_{\text {hitung diperoleh }}$ sebesar 9,139> $F_{\text {tabel }}$ sebesar 3,27 dengan tingkat signifikansi $0,000<$ 0,05. Karena tingkat signifikansi lebih kecil dari 0,05, sehingga dapat dikatakan bahwa capital adequacy ratio, ukuran bank dan resiko pembiayaan terhadap return on asset berpengaruh secara simultan (bersama-sama).

b. Hasil Uji t (Uji Secara Parsial)

Tabel 6

Hasil Uji t (Uji Secara Parsial)

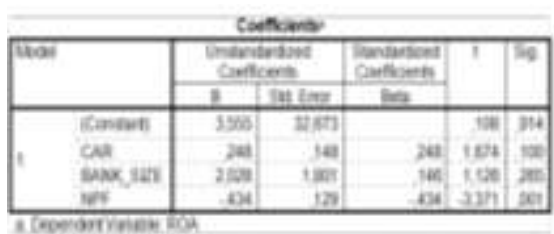

Berdasarkan hasil uji t terlihat variabel independen (resiko pembiayaan) berpengaruh secara parsial terhadap return on asset. Sedangkan variabel capital adequacy ratio dan ukuran bank tidak berpengaruh terhadap return on asset. 
JRNAL ПMПAH

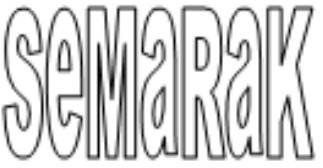

P-ISSN 2615-6849, E-ISSN 2622-3686

Jurnal Semarak,Vol.4,No.2,Juni 2021, Hal (67-80)

@Prodi Manajemen Fakultas Ekonomi Universitas Pamulang

\section{KESIMPULAN DAN SARAN}

\section{A. Kesimpulan}

Penelitian ini memiliki tujuan untuk mengetahui apakah terdapat pengaruh antara variabel independen (capital adequacy ratio, ukuran bank dan resiko pembiayaan) terhadap return on asset, untuk menganalisisnya maka dilakukan uji regresi linier berganda yang menghasilkan suatu analisa, setelah dianalisa maka dapat ditarik suatu kesimpulan, adapun kesimpulan dari penelitian ini adalah sebagai berikut:

1. Berdasarkan hasil uji regresi linier berganda secara parsial (uji t) ditemukan hasil yang menyatakan bahwa variabel capital adequacy ratio tidak berpengaruh secara parsial terhadap return on asset.

2. Berdasarkan hasil uji regresi linier berganda secara parsial (uji t) ditemukan hasil yang menyatakan bahwa variabel ukuran bank tidak berpengaruh secara parsial terhadap return on asset.

3. Berdasarkan hasil uji regresi linier berganda secara parsial (uji t) ditemukan hasil yang menyatakan bahwa variabel resiko pembiayaan tidak berpengaruh secara parsial terhadap return on asset.
4. Berdasarkan hasil uji regresi linier berganda secara simultan atau (uji F) ditemukan bahwa terdapat pengaruh yang signifikan pada variabel independen (capital adequacy ratio, ukuran bank dan resiko pembiayaan) terhadap return on asset.

\section{B. Saran}

Adapun penelitian ini akan bermanfaat bagi pihak-pihak tertentu yang dimanfaatkan sesuai dengan tujuanya, maka saran yang dapat diberikan adalah sebagai berikut:

1. Bagi pihak manajemen Bank Umum Syariah terus memperhatikan dan terus melakukan evaluasi kinerja pada bank umum syariah, khususnya pada indikator variabel ukuran bank dan kecukupan modal bank karena pada penelitian ini indikator ukuran bank dan kecukupan modal tidak memiliki pengaruh terhadap return on asset ban umum syariah dimana seharusnya apabila ukuran bank dan kecukupan modal bertambah besar akan berdampak menambahnya pendapatan laba bank umum syariah pula. Selain itu pihak manajemen bank harus menekan dan mengurangi rasio NPF atau pembiayaan bermasalah sebagai Risiko dari Pembiayaan.

2. Bagi Investor sebelum melakukan investasi sebaiknya memperhatikan 
JRNAL ПMПAH

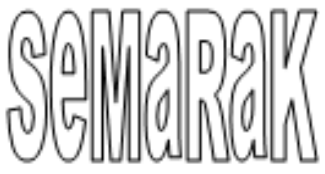

P-ISSN 2615-6849, E-ISSN 2622-3686

Jurnal Semarak,Vol.4,No.2,Juni 2021, Hal (67-80)

@Prodi Manajemen Fakultas Ekonomi Universitas Pamulang
Laporan Keuangan Bank Umum Syariah dan melihat bagaimana Risiko Pembiayaan atau yang diukur dengann Non Performing Financing (NPF) agar kedepannya investor tidak mengalami hal-hal yang tidak diinginkan, karena indikator NPF berpengaruh signifikan terhadap retun on asset Bank Umum Syariah di Indonesia Periode 20152019.

3. Bagi Akademisi atau peneliti selanjutnya diharapkan menjadi tambahan referensi bagi bank umum dan penelitian selanjutnya yang tertarik untuk meneliti dengan tema sejenis. Peneliti lain dapat menambahkan periode penelitian karena pada penelitian ini hanya menggunakan periode 5 tahun dan peneliti selanjutnya dapat menambahkan variabel lain yang belum ada dalam penelitian ini. Dan diharapkan penelitian selanjutnya dapat memperluas objek penelitian supaya mendapatkan hasil yang lebih akurat.

\section{DAFTAR PUSTAKA}

Ardi Murdoko Sudarmadji, L. S. (2007). Pengaruh Ukuran Perusahaan, Profitabilitas, Leverage, dan Tipe Kepemilikan Perusahaan Terhadap Luas Voluntary Disclosure Laporan Keuangan Tahunan. Universitas Gunadarma Vol 2.
Ascarya. (2015). Akad dan Produk Bank Syariah. Jakarta : PT RajaGrafindo Persada.

Barbosa, N. d. (2003). Corporate Performance : Does Ownership Matter? - and Domestic - Owned Firms in Greece and Portugal . Working Paper Series, 26.

Budi Santoso, T. d. (2006). Bank dan Lembaga Keuangan Lain. Jakarta: Salemba Empat.

Campbell, K. (2002). Ownership Structure and the Operating Performance of Hungarian Firms. Working Paper No 9.

Damayanti, P. (2012). Analisis Pengaruh Ukuran (Size), Capital Adequacy Ratio (CAR),Pertumbuhan Deposit, Loan to Deposit Rasio (LDR) terhadap Profitabilitas Perbankan Go Public di Indonesia Tahun 2005-2009. Jurnal Ilmu Manajemen dan Akuntansi Terapan (JIMAT) Vol.3 No.2.

Darmayanti, D. A. (2015). Pengaruh Risiko Kredit, Likuiditas, Kecukupan Modal, dan Efisiensi Operasional terhadap Profitabilitas pada BPD Bali. EJurnal Manajemen Unud Vol.4, No.9, 2590-2617.

Dendawijaya, L. (2009). Manajemen Perbankan, edisi kedua . Bogor : Ghalia Indonesia.

Edilius, S. d. (2010). Manajemen Koperasi Indonesia. Jakarta : Rineka Cipta.

Erma Setiawati, D. I. (2017). Pengaruh Kecukupan Modal, Risiko Pembiayaan,Efisiensi Operasional dan Likuiditas terhadap Profitabilitas. Riset Akuntansi dan Keuangan Indonesia. 
JRNAL ПMПAH

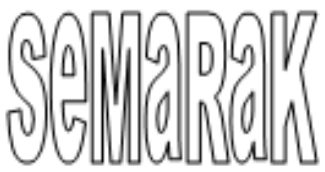

P-ISSN 2615-6849, E-ISSN 2622-3686

Jurnal Semarak,Vol.4,No.2,Juni 2021, Hal (67-80)

@Prodi Manajemen Fakultas Ekonomi Universitas Pamulang
Ghozali, I. (2013). Analisis Multivariat dan Ekonometrika Teori, Konsep dan Aplikasi dengan Eviews 8. Semarang : Badan Penerbit Universitas Diponegoro.

Hanafi, M. M. (2016). Analisis Laporan Keuangan. UPP STIM YKPN, Edisi kelima.

Hauner, D. d. (2005). Bank Efficiency and Competition in Low - Income Countries : The Case of Uganda. International Monetary Fund No 26.

Karim, A. (2007). Bank Islam: Analisis Fiqih dan Keuangan . Jakarta: PT RajaGrafindo Persada.

Kasmir. (2012). Analisis Laporan Keuangan. Jakarta: PT Raja Grafindo Persada.

Lukitasari, Y. P. (2014). Faktor-faktor yang Mempengaruhi Kinerja Keuangan pada Sektor Perbankan yang terdaftar di Bursa Efek Indonesia. Dinamika Akuntansi, Keuangan dan Perbankan Volume 3. Nomor 2.

Muhammad. (2014). Manajemen Dana Bank Syariah. Jakarta : Rajawali Pers.

Muhammad. (2014). Manajemen Dana Bank Syariah. Jakarta: Rajawali Pers.

Muhammad Syakhrun, A. A. (2019). Pengaruh CAR, BOPO, NPF dan FDR Terhadap Profitabilitas pada Bank Umum Syariah di Indonesia. Bongaya Journal for Research in Management.

Munir, M. (2018). Analisis Pengaruh CAR, NPF, FDR dan Inflasi terhadap Profitabilitas Perbankan Syariah di Indonesia. IHTIFAZ : Journal of Islamic Economics, Finance, and Banking Vol.1, No.1\&2.

Nunung indrawati, s. s. (2018). pengaruh capital adequacy ratio, non performing financibg,financing to deposit ratio, biaya operasional, dan pendapatan operasional, dan ukuran perusahaan terhadap return on asset bank umum syariah di indonesia. jurnal ekonomi dan kewirausahaan vol 18 no 2 juni $2018,253$.

Purnomo, S., \& Pasaribu, V. L. D. (2019). Pergerakan Harga Saham Pt Adaro Energy Tbk (Adro) Pada Pengumuman Dividen Interim Tahun Buku 2018. Jurnal Ekonomi Efektif, 2(1).

Pramono, E. S. (2017). Pengaruh CAR, NPL, BOPO, NIM DAN LDR terhadap ROA. Among Makarti Vol.10 No.19.

Prasetyo, W. (2015). Analis faktor-faktor yang Mempengaruhi Profitabilitas Perbankan. JESP Volume 7 No 1.

Rahmawati, M. N. (2015). Manajemen Risiko Perbankan Syariah. Ciputat: UIN Press.

Ramantha, A. Y. (2013). Analisis Pengaruh Rasio CAR, BOPO, LDR dan Ukuran Perusahaan terhadap Profitabilitas Bank yang Terdaftar di BEI . EJurnal Akuntansi Universitas Udayana 4.1, 230-245.

Rodoni, A. (2009). Investasi Syariah. Jakarta : Lembaga Penelitian UIN Jakarta.

Siamat, D. (2004). Manajemen Lembaga Keuangan . Jakarta: Lembaga Penerbit Fakultas Ekonomi Universitas Ekonomi.

Slamet Riyadi, Y. A. (2014). Pengaruh pembiayaan bagi hasil, pembiayaan jual beli, financing to deposit ratio (fdr), non performing financing (npf) terhadap profitabilitas bank umum syariah di Indonesia. Accounting analysis journal Fakultas Ekonomi Unnes Semarang.

Sufian, F. (2011). Profitability of the Korean Banking Sector: Panel Evidence on 
JRNAL ПMПAH

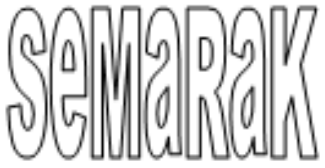

P-ISSN 2615-6849, E-ISSN 2622-3686

Jurnal Semarak,Vol.4,No.2,Juni 2021, Hal (67-80)

@Prodi Manajemen Fakultas Ekonomi Universitas Pamulang
Bank-Specific and Macroeconomic Determinants. Journal of Economics and Management, 43-72.

SUTIMAN, S. (2020). PENGARUH SET PELUANG INVESTASI, RASIO PEMBAYARAN DIVIDEN DAN BEBAN KEUANGAN TERHADAP PRICE BOOK VALUE PADA PERUSAHAAN MANUFAKTUR YANG TERDAFTAR DI BURSA EFEK INDONESIA PERIODE 20122016. JURNAL SeMaRaK,3(1), 2740.

Sugiyono. (2012). Metode Penelitian Kuantitatif Kualitatif dan $R \& D$. Bandung : Alfabeta.

Sumarlin. (2016). Analisis Pengaruh Inflasi, CAR, FDR, BOPO, dan NPF terhadap profitabilitas perbankan syariah. ASSETS 6 (2), 296-313.

Timan, S. (2017). ANALISIS SUMBER DAN PENGGUNAAN DANA DALAM UPAYA PENINGKATAN LIKUIDITAS DAN KEMAMPULABAAN PADA PT BANK $\mathrm{X}$ (PERSERO). Jurnal Mandiri: Ilmu Pengetahuan, Seni, dan Teknologi, 1(2), 289-310.

Timan, S. (2019). ANALISIS RASIO ROA DAN ROE DALAM MENILAI TINGKAT KESEHATAN PADA PT BANK MANDIRI (PERSERO) TBK TAHUN 2012-2017. Jurnal Mandiri: Ilmu Pengetahuan, Seni, dan Teknologi, 3(1), 20-36.

Tri Widiantoro Aji, J. S. (2017). Pengaruh Suku Bunga Kredit, Risiko Kredit dan Kecukupan Modal terhadap Profitabilitas. e-Jurnal Riset Manajemen Fakultas Ekonomi Unisma.
Wartono, T., Tumanggor, M., Oktrima, B., \& Delimah, V. L. (2021, January). Analysis of Ratio and Financial Performance of Open Company Pharmaceutical Industry Which has Been Listing in Indonesia Stock Exchange (Case Study in Pharmaceutical Company PT. Kimia Farma. Tbk). In INCEESS 2020: Proceedings of the 1st International Conference on Economics Engineering and Social Science, InCEESS 2020, 17-18 July, Bekasi, Indonesia (p. 268). European Alliance for Innovation. 